\title{
Increasing the Brand Awareness of Midtown Hotel Surabaya
}

\author{
Sitju Melinda Crishtine \\ English Department, Faculty of Letters, Petra Christian University, Surabaya, East Java, Indonesia \\ e-mail: m11414028@john.petra.ac.id
}

\begin{abstract}
A promotional video is important because it would increase the brand awareness of a product or service for brand awareness is closely associated with promotional tool. The goal here is to promote and introduce the product or service of a business to the public. Midtown Hotel Surabaya is a 3 - star hotel strategically located at Basuki Rahmat Street No. 76, Surabaya. The problem of Midtown Hotel Surabaya is the lack of promotional tools, especially in the form of promotional videos. Additional revenue is expected to increase through the promotional video. The portrayal of the pleasant staying experience one will get in a night is contained in the promotional video of Midtown Hotel Surabaya. The delicacy of food and beverage, comfortable bedding, and fast booking access would be the main selling points of the hotel. The video can be displayed in hotel or wedding exhibitions and Youtube to attract public's attention of Midtown Hotel Surabaya. Moreover, the video can also be utilized as a sales tool for the sales team on sales visits to companies who have not known about Midtown at all.
\end{abstract}

Key words: Promotional video, hotel, marketing video.

\section{INTRODUCTION}

Midtown Hotel Indonesia is a growing business hotel chain currently operating in five prominent cities in Indonesia such as Jakarta, Surabaya, Yogyakarta, Samarinda, and Sampit. Business people from middle to high class are the main target of the video.

During my 3-month internship, there are several problems of which the first one is the frequency of events for publicity of the hotel is below average. Approximately, only 1 event is held every 3 months while for comparison, Artotel Surabaya, another 3 - star hotel in Surabaya regularly holds events once in a month. This will result in the hotel getting more exposures and awareness if it is conducted regularly.

The second problem I found in Midtown Hotel Surabaya is that there is lack of human resources, especially in Sales \& Marketing department and Corporate department. The lack of human resources then leads into an inevitable situation where it is quite unclear who is doing what.

The third problem I found is the lack of promotional tools, especially for promotional videos. It is very important for a business to have a promotional tool for it increases the awareness of a product or service. As from what I have observed, I found that Midtown Hotel Surabaya does not have a promotional video in its website and social media. Moreover, a promotional video also serves as a sales tool for the sales team. I found that the sales team have been promoting the hotel and its products to their own market by using a single fact sheet which barely has any picture of the products at all and cannot enhance such a strong impression towards the brand. In my opinion, I do not think that it is an effective way to promote the hotel. Consumers are more interested in something which they can see in an instant such as videos and pictures. A promotional video would be an effective medium to build public's awareness toward the brand. Not only for the sales trips, but also for the publication agenda of the sales team such as an exhibition of hotels and wedding fair.

The problem of the project is how to increase the brand awareness of Midtown Hotel Surabaya. In fact, the hotel has not done any significant effort to handle this problem. Therefore, a promotional video would be the right solution to increase the brand awareness of Midtown Hotel Surabaya. This video is made for Midtown Hotel Surabaya. 
The purpose of the BCFP project is to make a promotional video for Midtown Hotel Surabaya. The promotional video serves many different purposes. As a promotional tool, the video can be displayed as a permanent channel of the hotel's TV in every room. As soon as the guests turn on the TV, the channel airing the promotional video will come out first. Other than that, the video can be utilized as a promotional tool to introduce the Midtown Hotel brand in hotel or wedding exhibition events. In those events, the video can be displayed in a monitor in order to catch the public's attention and introduce the brand. Moreover, the video can also be a sales tool for the hotel's sales team to introduce the brand to the potential customer, especially for companies that have not known Midtown yet. The sales team should utilize the video when they are doing sales visit to companies.

There are several principles that are applied to this project. According to Mullin, Hardy, and Sutton, (2014, p. 168), brand awareness is the ability of a consumer to name the brand's existence when its product category is mentioned. It is until the extent of which the consumers are familiar with the image of a particular brand. The development of brand awareness is very important for businesses to claim their existence in the market.

There are indeed countless ways to increase the public's awareness toward a brand. It could be through written mediums such as marketing booklet, press release, and brochure. Nevertheless, based on Yohn (2014, p. 169), one way to sharpen a brand is to shoot a brand documentary. A documentary in which it captures not just the products, but also what the brand stands for. Therefore, a promotional video that highlight the products' value and identity is the most effective solution to the problem since such contents are difficult to be portrayed well through written mediums.

According to Ruby (2012, pp. $5-6$ ), audio and video gradually replace text and pictures. Audio and video are taken as an extremely powerful medium that are used by many marketers and business owners. Ruby described some the benefits of marketing or promotional video as follows:

1. People are more willing to sit through a two - minute video than read a long blog entry.

2. A video is able to capture the visitors' attention in an entirely different way.

3. There are a lot of video platform which allow creators to spread the word.

4. Marketing video increased traffic, sales, and opt-ins.

According to Ruby (2012, p. 7), there are several features as a guideline to a good promotional video:

1. Demographic and target audience for a video is important.

2. Good videos are well - made and interesting.

3. Good videos provide valuable content.

4. Good videos should leave the audience thirsty for more.

\section{METHODS}

To execute the Business Communication Final Project, there are sets of procedures that have to be completed before, during, and after doing the project. The following are the procedures that were completed in making the promotional video for Midtown Hotel Surabaya.

First of all, I have to get the board of examiners approval. Not only the board of examiners' approval, but the approval from Midtown Hotel Surabaya regarding my project is also important. A proposal for the hotel which explains the background of the project, the purposes and the benefits that the hotel got from the project, and all the terms and conditions that have to be fulfilled is needed in order to give them insight on the project. Here are some steps to get the Company's approval of my proposal. First, I explained the basic concept of the project I had in mind to the Public Relation staff. The public relation staff then gave the permission to proceed to the next step. Second, a proposal for the company with all the terms and conditions was given to the Human Resource Department (HRD) admin of Midtown Hotel Surabaya to get the official permission from the hotel to do the shooting. The company proposal consists of the background of the project, the purpose and the benefit for the hotel from this project, and all the terms and conditions that have to be fulfilled. In terms and conditions, there is the statement that all the parties involved in the video production will not receive any fee. All the video shooting equipment will be provided by the cinematographer's colleague without any fee. The food and beverage properties will be covered by Midtown Hotel Surabaya. The job desks or role of every person participating in the production are included as well. I am the scriptwriter and director. Firmandy as the public relation staff is the cinematographer and 
editor. A marketing staff from Midtown Hotel Surabaya will be the actress and play the businesswoman role. All the other cameos in the video will be Midtown Hotel Surabaya's staff. There is a specific request on which staff who will be the cameos in the video. The request of using the highest room type of the Hotel is also mentioned. Last, the deadline for the shooting and editing process is written in the proposal as well.

The company proposal later was signed by both public relation staff and Human Resources administrator proposal and the official permission to do video shooting was gained.

After proposal and the official permission to do video shooting was gained, it is important to make a storyboard of the video before the shoot. After the storyboard is completed, a discussion session on the storyboard was held. After going through a couple of revisions, the script was finally done and the date of the shooting was decided.

After going through a couple of revisions, the script was finally done and the date of the shooting was decided. First of all, there was a short interview with the public relation on what needs to be highlighted in the video. After that, the cinematographer and I had a meeting on how to improve the script to make it better. After that, the cinematographer and I had a meeting on how to improve the script to make it better. The proposal then was signed by the HRD admin and the Public relation staff as the cinematographer and editor. As soon as after getting the official permission, the second meeting was discussing the date of the shooting and all the equipment needed for the shoot. Then, I confirmed the date to all the hotel's staff involved in the video. In the day of the shooting, me as the scriptwriter and the director instructed every single shot specifically. On average, it took almost 4 takes to get the perfect shot. It took approximately 10 hours to wrap up the shoot. The editor then showed me the first draft of the editing before the progress report with the board examiners so that I could give some inputs and get it revised before the first draft deadline. The following are the revisions from the Board of Examiners to make the video better:

a. additional scene

There is one additional scene in the video which is the bedroom scene. A shot of the bedroom is added in the video because it is classified as one of the most important aspects of the hotel. It is one thing that the viewers expect when they see a hotel promotional video.

b. deleted scenes

It is essential to make sure that all the cuts in the video are relevant for the content. Therefore, there are several irrelevant cuts that are omitted in order to achieve a video with a highly valuable content. The first removed cut is the businesswoman walking forward with her suitcase (Figure 4.1). The second one is the cut of a clock pointing at $10 \mathrm{a} . \mathrm{m}$. (Figure 4.2). Those two scenes are removed because it might bore the viewers for they take too much time for an opening of a hotel's promotional video. The main focus of the video should not be shifted. The experience in the hotel should be the main focus of the video instead of the airport scenes. Beside the airport scenes, the cut of the car's exterior is also removed. It is done to avoid misleading impression that the car in the video is Midtown Surabaya's car.

c. Change of the order

In order to keep the flow of story comprehensible, there are also some changes on the order of the scenes in the video to avoid any misinterpretation. First, the scene of the businesswoman entering the room. The next cut after the sweeping cut is changed into the cut of room facilities instead of meeting room to give a clear idea that the business woman enters the bedroom.

d. Language used

There are several further explanation in some scenes which are transcribed into short and concise texts in English. The texts are required in order to give more information and avoid misleading interpretation of the scenes. The English words used in the video are short, and concise, yet they are expected to convey the meaning of the video well.

Beside revisions on the first draft of the video, the Board of Examiners suggested to make an Instagram version of the video. For Instagram version of which the duration is shorter, there are some scenes of which the duration is shorten to fit into the time limit. There are ten scenes that were omitted to fit into the time limit. After some revision, the final video is finished.

\section{FINDINGS AND DISCUSSION}


The rational of the product will be elaborated in an orderly manner. The justification of every decision and selection of the scenes will be explained further as follows:

a. storyline

First of all, the concept of the video is a storyline of a businesswoman staying in the hotel for the first time. The plot goes from the businesswoman arrived on the airport from International flight. Then, she just booked a room in Midtown Hotel Surabaya right after she landed. After enjoying all the facilities in the Hotel such as restaurant and meeting rooms, she felt that trip is the most memorable one because of the service. She was satisfied and she had a good impression of Midtown Hotel Surabaya. Here, there are two goals of the promotional video. The first one is for the Hotel to introduce the brand to the public. The second one, looking from the consumers' point of view, the consumers get to follow the storyline well and get the impression of the staying experience in the hotel.

b. Duration

Based on Ruby (2012, p. 7), good videos should leave the audience thirsty for more. Highlighting the products in a short, concise, and simple video is better than a long one. In accordance to this principle, the promotional video's duration is less than 2 minutes. It is the proper length to catch the viewers' attention and yet, still maintains the audience's curiosity about the product for they see a sufficient amount of content, not too much, not too little.

c. Main Character

The reason of choosing a businesswoman as the main character in the video is because business people are the main target of the hotel. As stated in chapter 2, according to Ruby (2012, p. 7), demographic and target audience for a video is important. Who will watch the video should be a concern to business owners for it determines the 'voice' of the business. The selection of the main character is expected to portray Midtown Hotel Surabaya as the most suitable hotel for business people who are in their business trip.

However, as for the main character, businessmen are under represented in the video for there is only one businesswoman as the main character in the video while the target markets are businessmen and businesswomen.

d. Highlight

d.1 Service

To emphasize the main value of the hotel "serving with pride", it is best to portray the service given by the hotel. Couples of Midtown Surabaya's staff such as receptionist, concierge, waitress, and housekeeping are involved in the video. Moreover, the staff's uniforms shown in several scenes also enhance the color of Midtown Hotel Surabaya which is brown, gold, white, and black. The colors emphasize elegance and professionalism which reinforce the target market of the hotel, businesspeople. Another detail in the scene of the concierge opening the door is the watch. The watch worn by the concierge is shown to emphasize that time is highly valued by the hotel.

Another highlight on the service is the mobile application facility. The scene of the businesswoman booking the room via Midtown mobile application right after she landed is very essential. The purpose is to show how fast and convenient it is to book a room only a few hours before checking in as long as the room is available.

d.2 Bedroom

Bedroom is also one of the aspects that can not be neglected when making a promotional video of a hotel. A bedroom is one of the benchmark that determines whether the guest will be a loyal customer of the hotel or not. It plays a vital role in attracting the consumers. Other than being one of the most important aspect of the hotel, Midtown Hotel Surabaya's bedroom becomes the highlight because of the size. The type of bedroom in the video is the highest type available in Midtown Hotel Surabaya namely 'Marvelous Room' with $25,7 \mathrm{~m}^{2}$ in size. Compared to a -3 star Ibis Surabaya City Center Hotel in Basuki Rahmat which is the direct competitor of Midtown, Ibis only have one type of room with $18 \mathrm{~m}^{2}$ in size.

d.3 Meeting Rooms

Since Midtown Hotel Surabaya is a business hotel, meeting rooms have become one of the most critical facility of the hotel. Midtown itself have 5 meeting rooms namely, 'Midtown Halls'. It is important to highlight the meeting room for it shows the viewers the convenience for business people to have a meeting and a place to stay for the night in the same place. The meeting room scene 
uses meeting rooms number 2,3 , and 4 because those are the meeting rooms that can be merged into one big meeting halls. This following scene portrays the biggest meeting room in Midtown Hotel Surabaya.

d.4 Food and Beverage

The selection of the food in the video becomes one of the highlight in the video as well. The menus are chosen based on the specialty of the restaurant and the availability. The tenderloin steak and coffee latte in the video is one of signature dish and beverage in Townhall restaurant and they are not seasonal or promo menus. Seasonal or promo menus are not used in order to avoid any misinterpretation by the consumers who might think that the menus in the video are always available regardless the promo season. Moreover, the garnish plating scene is shown deliberately in order to imply that the chef is professional. As for the beverage, coffee is chosen instead of tea because Midtown specifically use a coffee brand namely TANAMERA which is quite well-known for coffee enthusiasts. The M-shaped coffee powder is also shown to emphasize the branding of Midtown Hotel Surabaya even more.

\section{CONCLUSION AND SUGGESTION}

The first and foremost step in doing the Business Communication Final Project, was to get the approval and permission from Midtown Hotel Surabaya to do the project. Other than that, an approval from the Board of Examiners to proceed with the project was also critical. After acquiring all the approvals from both the hotel and the Board of Examiners, I was able to execute the project. The video can be utilized as a promotion tool to introduce Midtown Hotel Surabaya to the public. The video can be displayed as a permanent channel of the hotel's TV in every room. The video can also be displayed in hotel or wedding exhibition events. In those events, the video can be displayed in a monitor in order to catch the public's attention and introduce the brand. Furthermore, the promotional video can be published on Youtube. Moreover, the video can also be a sales tool for the hotel's sales team to introduce the brand to the potential customer, especially for companies that have not known Midtown yet. For other students of English for Business Communication of Petra Christian University who plan to do the same Business Communication Project as mine, I suggest that they identify the problem existed in the place they are doing internship at and prepare more than one idea for the solution to the existing problem. Should it take a long time to get an approval from the internship class, one needs to propose an idea for the project in advance. After getting the approval, it is best for one to make a formal proposal to ask for permission along with further details especially about the funding to proceed with the project and get it all signed.

For the production or the shooting day, they should take weather and shooting hours into consideration in order to keep the lighting on the video consistent. Other than that, for post production or the editing process, it is important to have a good and clear communication between them and their video editor or the production house. They should deliver all the details and their expectation clearly to the editor so that the editor has the right picture of their expectation.

The promotional video is hopefully increasing the hotel's sales. Through a promotional video, more people will be aware of the hotel's brand. By having a good -quality promotional video, potential customers or partners can also look for Midtown's video as a reference.

\section{REFERENCES}

Mullin, B., Hardy, S., \& Sutton, W. (2014). Sport Marketing. United States: Human Kinetics.

Ruby, L. (2012). The Beginner's Guide to Video Marketing. Retrieved June 30, 2018, from http://rubymarketingsystems.com/pdfs/beginners-guide-to-video-marketing.pdf

Yohn, D. L. (2014). What Great Brands do. San Fransisco, California: Jossey-Bass. 